\begin{tabular}{|c|c|c|}
\hline \multirow[b]{2}{*}{ FYCEI I ENT } & $\begin{array}{l}\text { International Journal of Current Research in } \\
\text { Biosciences and Plant Biology }\end{array}$ & $E$ \\
\hline & Volume $5 \bullet$ Number 8 (August-2018)・ ISSN: 2349-8080 (Online) & 5 \\
\hline $\begin{array}{l}\text { EXCELLENT } \\
\text { PUBLISHERS }\end{array}$ & Journal homepage: www.ijcrbp.com & 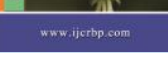 \\
\hline
\end{tabular}

\title{
Effect of Processed Vigna subterranea Seeds on Alkaline Phosphatase, Conjugated and Total Bilirubin Levels in Broiler Chickens Finishing Phase
}

\author{
R. U. Ukpanukpong1*, S. O. Bassey ${ }^{1}$, S. M. Ogunbode ${ }^{2}$, D. I. Basiru ${ }^{3}$, \\ W. A. Omang ${ }^{1}$ and M. U. Eteng ${ }^{1}$ \\ 1Department of Biochemistry, University of Calabar, Calabar-Nigeria \\ ${ }^{2}$ Department of Chemical Sciences Fountain University Osogbo, Ngeria \\ 3Department of Biochemistry, College of Natural Sciences, Joseph Ayo Babalola University, \\ Osun State, Nigeria \\ *Corresponding author.
}

\section{Article Info \\ Date of Acceptance: \\ 28 June 2018 \\ Date of Publication: \\ 06 August 2018}

\section{Keywords}

Alkaline phosphatase

Bilirubin

Body weight gain

Broiler chicken

\begin{abstract}
This study was conducted to investigate the effect of different processing methods of Bambara groundnut seed meal and its effects on tissue of broiler chickens. A total of eighty four day - old broiler chickens were weighed and randomly distributed into seven dietary treatments, three replicates of four birds per replicate. Each group was replaced with $40 \%$ of the processed Bambara groundnut (boiled, soaked, fermentation without decantation, fermentation with decantation, roasted and raw) respectively in place of soya bean meal. Soya bean meal based diet served as the control group, and the group treated raw Bambara groundnut meal serves as the negative control group. Liver, kidney and serum were studied by measuring the enzyme alkaline phosphatase (ALP), and conjugated and total bilirubin were considered. Body Weight Gain (BWG) was calculated as performance indices. Findings from this study indicated that ALP, conjugated and total bilirubin activities showed no significant differences $(P<0.05)$ in the serum, liver and kidney when compared with the control. The study showed that broiler chickens serum and kidney functions were not affected with the replacement of $40 \%$ of the various processed Bambara groundnut meal with soya bean meal.
\end{abstract}

\section{Introduction}

Bambara nut [Vigna subterranea (L.) Verdc.; Syn.: Voandzeia subterranea L.Thouars] belongs to the family of Leguminosae and it is widely grown in Nigeria because it can thrive well on soils too poor for groundnut (Arachis hypogea) (Poulter et al., 1980). The crops can also tolerate drought, it is grown mainly for its seeds which are used as part of food. It plays a role in traditional ceremonies as exchange of gift (Hepper, 1963, Oloyede et al., 2010 and Brough et al., 1993) reported that Bambara nut 
makes a balance food as it contains sufficient quantities of carbohydrate, protein and fats with relatively high proportions of lysine and methionine as percentage of the protein. Despite the protein quality in leguminous seeds, it does not however reach the same level as in animal products. This is due to unbalanced amino acids, presence of antinutritional factors and low digestibility of protein. Processing methods, such as soaking, cooking or fermentation can improve the quality of legume protein (Adebowale and Maliki, 2010). During fermentation, microflora may produce proteolytic enzymes which may be responsible for the increase in protein digestibility (Haseltine, 1983). Also, the elimination of phytic acid contributes to the improvement in protein digestibility of fermented products (Kheterpaul and Chauhan, 1991). The high carbohydrate $(65 \%)$ and relatively high protein $18 \%$ content of bambara groundnut make it a complete food (Doku, 1995). Bambara groundnut is probably the most drought resistant leguminous crop and may be found growing successfully where annual rainfall is below $500 \mathrm{~mm}$ and optimum between 900-1000 mm per year (Ocran et al., 1998).

An evenly distributed rainfall in the range 600$1000 \mathrm{~mm}$ encourages optimum growth but satisfactory yields can be obtained in areas with a pronounced dry season since the crop is relatively drought resistant (Messiaen, 1992). Bambara groundnut is resistant to high temperature and can be grown on poor marginal soils not suitable for other leguminous crops (Yamaguchi, 1983). Bambara groundnut is seldom attacked by pests and diseases in most of its production regions. However, in damp conditions, it may be susceptible to fungal diseases (Baudoin and Mergeai, 2001). In West Africa bambara groundnut (Vigna subterranea) was slightly ahead of cowpea (Vigna uniguiculata) in terms of production (market availability) and utilization. In Ghana, over 40,000 cans of different sizes of bambara groundnut were produced annually throughout the 1960's and early 1970's. The canned product was very popular throughout West Africa and competed favourably with Heinz baked beans. The status of the nut however, started to decline from 1970's with introduction of high yielding varieties of Arachis hypogaea and pest control methods for cowpea (Doku, 1996).The protein of Bambara groundnut is of good quality and has surplus lysine which complements cereals in the diet (Ocran et al., 1998). It is high in protein but unlike ordinary groundnuts contains very little oil (Tweneboah, 2000). Bambara groundnut has been ranked as the third most important grain legume, after Arachis hypogaea and cowpea (Vigna unguiculata) in semi-arid Africa, but has not been accorded due attention in research (Rachie and Silvester, 1977). Bambara groundnut, (Vigna subterranea $(L)$ Verdc.) is of West African origin and has been cultivated in tropical Africa for centuries (Yamaguchi, 1983). Bambara groundnut is an indigenous African leguminous crop and one of the most important pulses grown on the continent (Doku and Karikari, 1969). The crop has been widely cultivated in tropical regions since the seventeenth century. In addition to sub-Saharan Africa, it is now found in many parts of South America, Asia and Oceania (Baudoin and Mergeai, 2001).The centre of origin of bambara groundnut is probably north eastern Nigeria and northern Cameroon. It is now cultivated throughout tropical Africa and to a lesser extent in tropical parts of America, Asia and Australia (Brink et al., 2006).

\section{Materials and methods}

\section{Sample collection and processing}

The experiment was conducted at the animal house Biochemistry and Nutrition unit of the Department of Chemical Sciences, Fountain University Osogbo, Osun State, Nigeria. The Bambara groundnut seeds were purchased from Wukari market, Taraba State and the processing of Bambara groundnut seeds was done in Fountain University in Osogbo, Osun State. Seven different processing methods were carried out and seeds were rinsed before the commencement of each processing methods.

Boiling: This was carried out by pouring $1 \mathrm{~kg}$ of the Bambara groundnut into a cooking pot containing 8 litres of water at $100^{\circ} \mathrm{C}$ set over fire. This was boiled for 1 hour until it was well cooked. The water 
was sieved out and the nuts were sun dried for 3-4 days before milling.

Soaking: The Bambara groundnut was soaked by pouring $1 \mathrm{~kg}$ of the seeds into 8 litres of water for 12 hours and the water was sieved out and the seeds were sun dried sun for 3-4 days before milling into powdery form.

Fermentation: This was carried out in two different processes;

Without decantation: This was done by pouring $1 \mathrm{~kg}$ of the seeds into 8litres of water in an air-tight container and soaked for $12 \mathrm{hrs}$. The fermentation process started immediately after $12 \mathrm{hrs}$ without sieving out the water. The water was sieved out after $48 \mathrm{hrs}$ and the seeds were sun dried for 3-4 days before milling into powdery form.

With decantation: This was done by pouring $1 \mathrm{~kg}$ of the seeds into 8litres of water in an air-tight container and soaked for $12 \mathrm{hrs}$ as similar to the soaking process. The water was sieved out and another 8litres of water was poured into it and it was well covered and the fermentation process started immediately after sieving. The water was then sieved out after $48 \mathrm{hrs}$ and the seeds were sun dried for 3-4days before milling into powdery form.

Toasting: Toasting of the Bambara groundnut was done by pouring $1 \mathrm{~kg}$ of the seeds into a frying pan containing fine sand set over fire. The seeds were stirred to avoid excessive burning. The stirring of the seeds while on fire was continuous until it turns brownish. Excessive burning was avoided so as not to completely destroy the essential amino acids. The toasted seeds were then milled into powdery form.

Raw Bambara groundnut: The seeds were rinsed with clean water and dried under the sun after which they were later were milled and sieved so as to remove the seed coat.

\section{Experimental diets and management of animals}

The experimental diets used were prepared in a section of the animal house unit under the Biochemistry and Nutrition laboratory of Chemical Sciences Department, Fountain University Osogbo, Osun state, where the study was carried out. Seven diets were prepared: A total of 84 day-old broiler chicks were purchased from Arbor Acre strain, RTO Farms, Osogbo hatchery; they were wing banded, weighed and randomly allocated to seven dietary treatments of four birds per treatment. The birds were housed in a well illuminated and ventilated poultry house. Feed and water were provided ad libitum. The chicks were vaccinated against Newcastle disease virus (lasota vaccine) at day 8 of age, and against Infectious Bursal Disease (IBD) virus at day 10 of age via drinking water. The body weights of birds were determined on weekly basis to allow for calculation of weight gained, feed intake and feed conversion ratio. The study lasted four weeks.

\section{Proximate analysis}

The test sample of Bambara groundnut ( $V$. subterranea) was subjected to proximate analysis according to the methods outlined by AOAC (2010).

\section{Moisture determination}

Moisture was determined by the loss in weight that occurs when a sample was dried to a constant weight in an oven. $1 \mathrm{~g}$ each of the processed feeds sample weighed into a crucible previously dried and weighed. The sample was then dried in an oven at $85^{\circ} \mathrm{C}$ for 24 hours, cooled in a desiccator for about 15 minutes and weighed.

$$
\% \text { Moisture }=\{(\mathrm{I}-\mathrm{F}) / \mathrm{I}\} * 100
$$

Where, I= Initial weight of sample + crucible before drying; $\mathrm{F}=$ Final weight of sample + crucible after drying.

Since the water content of feed varied widely, ingredients and feed are usually compared for their nutrient content on moisture free or dry matter (DM) basis. 


\section{Calculation}

$$
\begin{gathered}
\% \text { Moisture }=\frac{\text { Loss in weight }}{\text { Weight of sample before drying }} \times 100 \\
\frac{W_{2}-W_{3}}{W_{2}-W_{1}} \times 100
\end{gathered}
$$$$
\% \text { Total Solid or } \% \text { Dry matter }=\frac{W_{3}-W_{1}}{W_{2}-W_{1}} \times 100
$$

Alternatively \% Total Solid $=100-\%$ Moisture $\% \mathrm{DM}=100-\%$ Moisture.

\section{Ether extract}

The ether extract of a feed represents the fat and oil in the feed. Soxhlet apparatus was the equipment used for the determination of ether extract. Soxhlet apparatus is made up of 3 component; condenser, extractor, and round bottom flask.

$$
\% \text { Ether extract }=\{(\mathrm{I}-\mathrm{F}) / \mathrm{I}\} * 100
$$

Where,

I= Initial weight of sample + filter paper before drying; $F=$ Final weight of sample +filter paper after drying.

\section{Crude fibre}

The organic residue left after sequential extraction of feed with ether can be used to determine the crude fibre. However, a fresh sample was used for this analysis.

$\%$ Crude fibre $=\{(\mathrm{I}-\mathrm{F}) / \mathrm{I}\} * 100$

Where, I= Initial weight of sample + filter paper before boiling; F= Final weight of sample + filter paper after boiling.

\section{Crude protein}

Crude protein was determined by measuring the nitrogen content of the feed and multiplying it by a factor of 6.25. This factor is based on the fact that most protein contains $16 \%$ nitrogen. Crude protein is determined by Kjeldahl method. The method involves: Digestion, Distillation and titration.

$$
\% \mathrm{~N}=0.00014 * \mathrm{VA} * 100 * \mathrm{~W} * 6.25
$$

$\mathrm{VA}=$ volume of acid used, $\mathrm{W}=$ weight of sample

\section{Ash content}

Ash is the inorganic residue obtained by burning off the organic matter of feedstuff at $550-600^{\circ} \mathrm{C}$ in muffle furnace for $3 \mathrm{hrs}$. $1 \mathrm{~g}$ of the sample was weighed into a pre-heated crucible. The crucible was placed into muffle furnace at $550-600^{\circ} \mathrm{C}$ for $3 \mathrm{hrs}$. The crucible was then placed in the desiccator and weighed.

$\%$ Ash $=\{(\mathrm{I}-\mathrm{F}) / \mathrm{I}\} * 100$

Where I= Initial weight of sample + crucible before ashing; F= Final weight of sample +crucible after ashing.

\section{Nitrogen free extract (NFE)}

NFE represents soluble carbohydrates and other digestible and easily utilizable non-nitrogenous substances in feed. NFE was determined by mathematical calculation. It was obtained by subtracting the sum of percentages of all the nutrients already determined from 100 .

$$
\% \mathrm{NFE}=100-(\% \text { moisture }+\% \mathrm{CF}+\% \mathrm{CP}+\% \mathrm{EE}+\% \mathrm{Ash})
$$

\section{Blood collection and tissue preparation}

At the end of the feeding trial, the broilers were starved overnight so as to empty the crop. Blood samples were collected via jugular vein. Two birds per replicate were randomly selected, weighed and sacrificed. Serum was separated by centrifugation (3000 revolution per minutes). The serum was collected using Pasteur pipette and kept frozen until needed. The de-feathered broilers were dissected and the organs of interest were then removed, cleaned with tissue paper and weighed. The sample 
of organs collected were homogenized using mortar and pestle in an ice cold $0.25 \mathrm{M}$ sucrose solution so as to maintain the integrity of the tissue till required, according to the method of Ogbu and Okechukwu (2001).

\section{Estimation of biochemical parameters}

Biochemical estimations were carried to ascertain the integrity of and efficiency of the organs (kidney and liver). The measurement of the sample blood serum activities of the enzymes is helpful diagnosis index to determine the functionality level of the organs.

Determination of alkaline phosphatase: The method of Thomas and Wofford (1993) as employed in the Reflotron assay kit was used.

Estimation of total and conjugated bilirubin: Serum bilirubin was determined by the use of Randox laboratory reagents kits method (Owens and Sherlock, 1973).

\section{Statistical analysis}

All experimental values were represented as means of $\pm \operatorname{SEM}(n=3)$. Analysis of variance (ANOVA) followed by Duncan and Tukey-Kramer test for differences between means were used to detect significant differences $(P<0.05)$ between the variables used in this study.

\section{Results and discussion}

The data in Table 1 summarizes the proximate composition of different processed Bambara groundnut seeds, with the raw Bambara groundnut seed having the highest crude protein compared with others. The soaked seed had the highest crude fibre in relation to other processed seeds. The soaked Bambara seed had the highest inorganic residues (ash), raw Bambara seed had the highest oil content (ether extract) while raw Bambara seed had the highest nitrogen free extract. Table 2 shows the result of the proximate composition of the different formulated diets using Bambara seed. The negative diet with raw Bambara groundnut seed meal had the least crude protein content of $22.58 \%$. Table 3 explains the result of proximate nutrient composition for finisher phase of the formulated Bambara groundnut seed meal. Statistically, diet with boiled Bambara groundnut seed meal had the least protein content of 22.84. Table 4 summarizes the weight gained by broiler chickens fed with different diets of Bambara groundnut seed meal. Statistically, broiler chickens fed with different processed Bambara groundnut seed meals showed no significant $(\mathrm{P}>0.05)$ differences when compared with the control groups, but numerically, birds fed with raw and boiled groundnut seed had the highest daily weight gain of $1.573 \mathrm{~g}$.

Table 2 elucidates the result of the proximate composition of the formulated diets (starter phase) using Bambara seed. Raw Bambara groundnut seed meal had the least crude protein content $20.38 \%$ which may be due to the presence of the secondary metabolites that is, the anti-nutritional factors such as saponins and tannin binding the protein. Table 3 explains the proximate composition for (finisher phase) of the formulated diets using Bambara groundnut seeds. The processed diet with fermentation without decantation Bambara groundnut seed meal had the least crude protein content $18.02 \%$ which may be due to the presence of the secondary metabolites that is, the antinutritional factors such as tannin and saponins binding the protein.

Table 4 explains the result of final weight gain of broiler chickens fed with various Bambara groundnut seed meal. There was no significant difference between the weight gain of the chickens fed with fermentation without decantation Bambara seed and raw Bambara seed when compared with the control, while there was significant difference between boiled, soaked, fermentation with decantation, and roasted Bambara groundnut seed compared with the control. The results on specific activities of conjugated and total bilirubin in the serum of broiler chickens fed with different processed Bambara groundnut meal replacement diets are shown in Table 5. 
Table 1. Proximate composition (g/100gDM) of the different processed Bambara groundnut seed meal (starter phase).

\begin{tabular}{lllllll}
\hline Analysis (\%) & BBG & SBG & FBG (wo) & FBG (w) & RBG & Raw \\
\hline Crude protein & 22.64 & 22.73 & 22.72 & 22.73 & 28.59 & 22.58 \\
Dry matter & 90.74 & 92.52 & 93.20 & 92.45 & 91.59 & 93.45 \\
Crude fibre & 8.71 & 10.17 & 9.84 & 9.61 & 8.79 & 8.13 \\
Ash & 2.44 & 2.18 & 2.46 & 2.19 & 2.40 & 2.24 \\
Ether extract & 7.65 & 7.82 & 7.79 & 7.85 & 7.59 & 7.9 \\
NFE & 49.3 & 49.62 & 50.39 & 50.07 & 44.22 & 52.6 \\
\hline
\end{tabular}

$\mathrm{BBG}=$ Boiled Bambara groundnut, $\mathrm{SBG}=$ Soaked Bambara groundnut, FBG $($ wo $)=$ Fermentation without decantation, FBG $(w)=$ Fermentation with decantation, $\mathrm{RBG}=$ Roasted $\quad$ Bambara Groundnut, NFE $=$ Nitrogen Free Energy.

Table 2. Proximate composition $(\mathrm{g} / 100 \mathrm{gDM})$ of the formulated diets with Bambara groundnut seed meal (starter phase).

\begin{tabular}{llllllll}
\hline $\begin{array}{l}\text { Analysis } \\
(\boldsymbol{\%})\end{array}$ & $\begin{array}{l}\text { Normal } \\
\text { control }\end{array}$ & BBG & SBG & FBG (wo) & FBG (w) & RBG & Raw \\
\hline DM & 92.45 & 90.74 & 92.52 & 93.20 & 92.45 & 91.59 & 93.45 \\
CP & 20.62 & 20.40 & 20.64 & 20.40 & 20.53 & 20.41 & 20.38 \\
CF & 3.29 & 3.89 & 3.92 & 3.99 & 3.96 & 3.82 & 3.88 \\
Ash & 2.98 & 3.15 & 2.89 & 2.82 & 3.04 & 2.84 & 2.89 \\
EE & 8.29 & 7.89 & 7.80 & 8.49 & 8.96 & 8.52 & 8.58 \\
NFE & 56.48 & 54.44 & 54.87 & 56.03 & 54.05 & 53.98 & 57.31 \\
\hline
\end{tabular}

$\mathrm{BBG}=$ Boiled Bambara groundnut, $\mathrm{SBG}=$ Soaked Bambara groundnut, FBG $($ wo $)=$ Fermentation without decantation, FBG $(w)=$ Fermentation with decantation, $\mathrm{RBG}=$ Roasted $\quad$ Bambara Groundnut, $\mathrm{CP}=\mathrm{Crude}$ Protein, $\mathrm{DM}=$ Dry matter, $\mathrm{CF}=$ Crude fibre, $\mathrm{EE}=$ Ether extract, NFE = Nitrogen Free Energy.

Table 3. Proximate composition ( $\mathrm{g} / 100 \mathrm{gDM})$ of the formulated Bambara groundnut seed meal (finisher phase).

\begin{tabular}{llllllll}
\hline $\begin{array}{l}\text { Analysis } \\
(\boldsymbol{\%})\end{array}$ & $\begin{array}{l}\text { Normal } \\
\text { control }\end{array}$ & BBG & SBG & FBG (wo) & FBG (w) & RBG & Raw \\
\hline CP & 18.28 & 18.04 & 18.03 & 18.02 & 18.08 & 18.09 & 18.08 \\
DM & 92.54 & 92.31 & 92.00 & 92.52 & 92.38 & 92.52 & 91.84 \\
CF & 3.32 & 3.56 & 3.65 & 3.62 & 3.61 & 3.56 & 3.67 \\
Ash & 2.67 & 2.61 & 2.15 & 2.45 & 2.34 & 2.72 & 2.79 \\
EE & 5.60 & 5.55 & 5.83 & 5.79 & 5.85 & 5.55 & 5.9 \\
NFE & 62.67 & 62.55 & 62.44 & 62.64 & 62.52 & 62.6 & 61.2 \\
\hline
\end{tabular}

$\mathrm{BBG}=$ Boiled Bambara groundnut, $\mathrm{SBG}=$ Soaked Bambara groundnut, FBG (wo) $=$ Fermentation without decantation, FBG $(\mathrm{w})=$ Fermentation with decantation, $\mathrm{RBG}=$ Roasted $\quad$ Bambara groundnut, $\mathrm{CP}=\mathrm{Crude}$ Protein, $\mathrm{DM}=$ Dry matter, $\mathrm{CF}=$ Crude fibre, $\mathrm{EE}=$ Ether extract, NFE = Nitrogen Free Energy. 
Table 4. Weight gain analysis of the broiler chickens fed with different processed Bambara groundnut seed meal based diets.

\begin{tabular}{llll}
\hline Dietary treatment & Initial weight & Final weight & Weight gained/bird/day (g) \\
\hline Treatment 1 (Control) & $0.116 \pm 0.01^{\mathrm{c}}$ & $1.600 \pm 0.13^{\mathrm{b}}$ & $1.483 \pm 0.12^{\mathrm{b}}$ \\
Treatment 2 (RBG) & $0.117 \pm 0.01^{\mathrm{c}}$ & $1.525 \pm 0.09^{\mathrm{d}}$ & $1.408 \pm 0.08^{\mathrm{d}}$ \\
Treatment 3 (BBG) & $0.116 \pm 0.01^{\mathrm{c}}$ & $1.542 \pm 0.14^{\mathrm{c}}$ & $1.425 \pm 0.13^{\mathrm{c}}$ \\
Treatment 4 (SBG) & $0.123 \pm 0.01^{\mathrm{b}}$ & $1.633 \pm 0.11^{\mathrm{ab}}$ & $1.510 \pm 0.10^{\mathrm{b}}$ \\
Treatment 5 (FBG w) & $0.125 \pm 0.00^{\mathrm{ab}}$ & $1.594 \pm 0.12^{\mathrm{bc}}$ & $1.469 \pm 0.12^{\mathrm{bc}}$ \\
Treatment 6 (FBG) (wo) & $0.128 \pm 0.00^{\mathrm{a}}$ & $1.700 \pm 0.57^{\mathrm{a}}$ & $1.573 \pm 0.57^{\mathrm{a}}$ \\
Treatment 7 (Raw) & $0.116 \pm 0.01^{\mathrm{c}}$ & $1.690 \pm 0.01^{\mathrm{a}}$ & $1.573 \pm 0.09^{\mathrm{a}}$ \\
\hline
\end{tabular}

The results are mean \pm SEM of 2determinations. The weights gained are expressed as in $\mathrm{kg}$. Values of treatment 6and 7 had no significant $(P<0.005)$ differences and both processing method (Raw and fermentation without) had a favourable weight gain compared with the control. The results carrying different letters were significantly different $(P<0.005)$. a, b, c, d, e are means within the same columns with different superscripts that are significantly different.BBG $=$ Boiled Bambara groundnut, $\mathrm{SBG}=$ Soaked Bambara groundnut, FBG (wo) = Fermentation without decantation, $\mathrm{FBG}(\mathrm{w})=$ Fermentation with decantation, $\mathrm{RBG}=$ Roasted Bambara Groundnut, NFE $=$ Nitrogen Free Energy.

Table 5. Specific activities of conjugated and total bilirubin in the serum of broiler chickens fed with different processed Bambara groundnut meal replacement diets.

\begin{tabular}{lll}
\hline Dietary treatment & Total bilirubin & Conjugated bilirubin \\
\hline Treatment 1 (Control) & $7.17 \pm 0.75^{\mathrm{a}}$ & $2.50 \pm 0.54^{\mathrm{cd}}$ \\
Treatment 2 (RBG) & $4.67 \pm 0.81^{\mathrm{bc}}$ & $2.17 \pm 0.41^{\mathrm{d}}$ \\
Treatment $3(\mathrm{BBG})$ & $5.00 \pm 0.89^{\mathrm{bc}}$ & $3.83 \pm 0.98^{\mathrm{ab}}$ \\
Treatment $4(\mathrm{SBG})$ & $7.17 \pm 0.98^{\mathrm{a}}$ & $4.67 \pm 1.21^{\mathrm{a}}$ \\
Treatment 5 (FBG w) & $4.17 \pm 0.75^{\mathrm{c}}$ & $2.67 \pm 0.51^{\mathrm{cd}}$ \\
Treatment 6 (FBG wo) & $4.67 \pm 0.82^{\mathrm{bc}}$ & $3.33 \pm 0.51^{\mathrm{bc}}$ \\
Treatment 7 (Raw) & $5.33 \pm 0.51^{\mathrm{b}}$ & $2.33 \pm 0.51^{\mathrm{d}}$ \\
\hline
\end{tabular}

The results are mean \pm SEM of 2 determinations. The weights gained are expressed as in $\mathrm{kg}$. Values of treatment 6 and 7 had no significant $(P<0.005)$ differences and both processing method (Raw and fermentation without) had a favourable weight gain compared with the control. The results carrying different letters were significantly different $(P<0.005)$. a, b, c, d, e are means within the same columns with different superscripts that are significantly different.BBG= Boiled Bambara groundnut, $\mathrm{SBG}=$ Soaked Bambara groundnut, $\mathrm{FBG}($ wo $)=$ Fermentation without decantation, $\mathrm{FBG}(\mathrm{w})=$ Fermentation with decantation, $\mathrm{RBG}=$ Roasted Bambara Groundnut, NFE $=$ Nitrogen Free Energy.

Activities of enzymes in the serum reflect the pathological and physiological state of the kidney and liver tissues. Alkaline phosphate is a marker enzyme for plasma membrane and endoplasmic reticulum, and it is use to assess the integrity of plasma membrane. ALP functions in the transfer of ions and metabolite across the cell membrane by hydrolysis of phosphate ester in alkaline medium. Phosphatases, including ALP play an important role in detoxification, metabolism and biosynthesis of energetic macromolecules for various essential functions. The specific activities of alkaline phosphatase in the serum, liver and kidney are shown in Table 6 . There were no significant 
$(\mathrm{P}>0.05)$ differences in the values of the specific activity of the alkaline phosphatase in the liver and kidney of broiler chickens in all the treatment groups when compared with the control. Also the activity of the liver and kidney alkaline phosphatase depicted no sign of leakage of the enzymes into the serum in all the birds given Bambara seed meal at $5 \%$ replacement value compared with those on soya bean meal based diets (control group). Conjugated and total bilirubin are useful diagnostic tools for liver diseases. The accumulation of bilirubin in the tissue, as a result of jaundice may cause elevation of total bilirubin (Murray, 2003). There are no significant $(\mathrm{P}>0.05)$ differences in the values of the conjugated and total bilirubin in all treatment groups when compared with the control group except fermented without decantation treatment group that depicted an increase in total and conjugated bilirubin. There are a compendium of clinical conditions that manifest in jaundice due to a shift in the equilibrium between the production and clearance of bilrubin. These clinical conditions include excessive production of bilirubin as in the case of haemolytic anaemia, reduced hepatocyte uptake bilirubin as in the liver subjected to potential damage damage from some pharmaceutical and environmental chemicals, impaired conjugated bilirubin decreased hepatocellular excretion and impaired intra hepatic and extrahepatic bile flow (Crawfor, 1999). Findings from this research showed that replacing Bambara groundnut seed meal at $40 \%$ against soya bean meal had no adverse effect on the performance and enzyme activities of the serum, liver and kidney of broiler chickens, indicating that the plasma membrane was not compromised, this is not in agreement with the findings of (Oloyede et al., 2007) which claimed that birds placed on raw, roasted and fermented Bambara groundnut seed meal based diet showed significant increase in alkaline phosphatase.

Table 6. Specific activities of Alkaline Phosphatase in the serum, liver and kidney of broiler chickens fed with 40 different processed Bambara groundnut meal replacement diets.

\begin{tabular}{|c|c|c|c|}
\hline Dietary treatments & Serum & Liver & Kidney \\
\hline Treatment 1 (Control) & $1.670 \pm 0.07^{\mathrm{b}}$ & $0.783 \pm 0.04^{\mathrm{b}}$ & $1.262 \pm 0.04^{\mathrm{c}}$ \\
\hline Treatment 2 (RBG) & $2.003 \pm 0.05^{\mathrm{a}}$ & $1.240 \pm 0.04^{\mathrm{a}}$ & $1.338 \pm 0.05^{\mathrm{b}}$ \\
\hline Treatment 3 (BBG) & $1.745 \pm 0.07^{\mathrm{b}}$ & $1.230 \pm 0.06^{\mathrm{b}}$ & $1.700 \pm 0.03^{\mathrm{a}}$ \\
\hline Treatment 4 (SBG) & $1.255 \pm 0.10^{\mathrm{d}}$ & $1.282 \pm 0.07^{\mathrm{a}}$ & $1.213 \pm 0.03^{\mathrm{c}}$ \\
\hline Treatment 5 (FBG w) & $1.210 \pm 0.03^{\mathrm{de}}$ & $1.247 \pm 0.06^{\mathrm{a}}$ & $1.227 \pm 0.05^{\mathrm{c}}$ \\
\hline Treatment 6 (FBG wo) & $1.152 \pm 0.05^{\mathrm{e}}$ & $1.235 \pm 0.07^{\mathrm{a}}$ & $1.128 \pm 0.04^{\mathrm{d}}$ \\
\hline Treatment 7 (Raw) & $1.537 \pm 0.05$ & $1.222 \pm 0.06^{\mathrm{a}}$ & $1.143 \pm 0.30^{\mathrm{d}}$ \\
\hline
\end{tabular}

\section{Conclusion}

The beneficial effects associated with the use of Bambara groundnut seed is the focus of this research. The result obtained from these investigation showed that liver and kidney of broiler chickens (starter phase) were not compromised when their diet was replaced with
$40 \%$ Bambara groundnut seed meal in place of soya bean meal. It further depicted that there was no leakage of enzymes into the serum at $40 \%$ replacement level of Bambara groundnut seed meal. This further indicate that broiler chicken (starter phase) diet composition containing 40\% Bambara groundnut seed meal will not have negative effect on the liver and kidney. 


\section{Conflict of interest statement}

Authors declare that they have no conflict of interest.

\section{References}

Adebowale, O. J., Maliki, K., 2011. Effect of Fermentation period on the chemical composition and functional properties of pigeon peas (Cajanus cajan) seed flour. Int. Food

Res. J. 18(4), 1329-1333.

A.O.A.C., 2010. Official Methods of Analysis of the Association of Official Analytical Chemists Washington, D.C. USA. $22^{\text {nd }}$ Edn. Vol. 2 pp. 69.

Baudoin, J. P., Mergeai, G., 2001. Grain Legumes. In: Crop Production in Tropical Africa (Ed.: Raemaeker, R.), Directorate Generale for International Cooperation, Brussels. pp. 313317.

Brink, M., Ramolemana, G.M., Sibuga, K.P., 2006. Vigna subterranean (L.) Verdc. In: Plant Resources of Tropical African 1. Cereals and Pulses (Eds.: Brink, M., Belay, G.). pp. 56-90.

Brough, S.H., Azam-Ali, S.N., Taylor, A.J., 1993. The potential of Bambara groundnut (Vigna subterranea) in vegetable milk production and basic protein functionality systems. Food Chem. 47, 277-283.

Crawfor, J. M., 1999. The liver and biliary tract. In: Robbins Pathologic Basis of Disease (Ed.: Cotran, R.S., Kumar, V., Collins, T.). $6^{\text {th }}$ Edn. 845-900). Philadelphia, L.B. Lippincott Company.

Doku, E.V., 1995. University of Ghana. In: Proceedings of the Workshop on Conservation and Improvement of Bambara groundnut (Vigna subterranean (L.) Verdc) Harare Zimbabwe, 31, 17-26.

Doku, E.V., 1996. Problems and prospects for the improvement of Bambara groundnut. In: Proceedings of the International Bambara Groundnut Symposium. University of Nottingham, UK. pp.41-74.

Doku, E.V., Karikari, S.K., 1969. Faculty of Agriculture, University of Ghana, Legon,
Ghana. Flowering and pod production of Bambara groundnut (Vigna subterranean) in Ghana. Ghana J. Agric. Sci. 3(1), 17-30.

Hepper, F.N., 1963. Plants of the 1957-58 West Africa Expedition II: The bambara groundnut (Voandzeia subterranea) and Kersting's groundnut (Kerstingiella geocarpa) wild in West Africa. Kew Bull. 16, 395-407.

Heseltine, C.W., 1983. The future of fermented foods. Nutr. Rev. 41, 293-301.

Khetarpaul, N., Chauhan, B. M., 1991. Effect of natural fermentation on phytate and polyphenol content and in vitro digestibility of starch and protein of pearl millet (Pennisetum typhoideum). J. Sci. Food Agric. 55, 189-195.

Messiaen, C.M., 1992. The Vegetable Garden, Macmillan Press Limited. 318p.

Moss, P., 1961. Limits of interference by Fe, Mn, Al and phosphate in the EDTA determination of calcium in the presence of magnesium using cal-red indicator. J. Sci. Food Agric. 12, 30-34.

Murray, R.K., 2003. Porphyrins and Biles pigments. In: Harpers`s Illustrated Biochemistry. (Eds.: Murray, R.K., Granner, D. K., Mayes, P. A., Rodwell, V. W.), $26^{\text {th }}$ Edn. 270-285). The McGraw-Hall Companies Inc., New York.

Ocran, V. K., Delimini, L. L., Asuboah, R.A., Asiedu, E.A., 1998. Seed Management Manual for Ghana, MOFA, Accra Ghana. Vol. 2. pp.482.

Okonkwo, S.I., Opara, M.F., 2010. The Analysis of Bambara nut for sustainability in Africa. Res. J. Appl. Sci. 5(6), 394-396.

Oloyede, O. B., Odutuga, A.A., Minari, J. B., Amballi, 2007. Assessment of some serum metabolites and enzymes of broiler-chickens fed raw and processed Bambara groundnut. Int. J. Poult. Sci. 6(9), 647-650.

Oloyede, O. B., Minari, J. B., Muhammad, N. O., 2010. Evaluation of growth characteristics and heamatological indices of broiler chicks fed raw and processed Bambara groundnut seed as a component of poultry feed. Int. J. Poult. Sci. 9, 652-655.

Owens, D., Sherlock, S., 1973. Diagnosis of Gilbert's syndrome: role of the reduced caloric 
intake test. Brit. Med. J. 3, 559-563.

Poulter, N. H., Caygill, J. C., 1980. Vegetable milk processing and rehydration characteristic of Bambara groundnut (Voandzeia subterranea (L.) Thouars). J. Sci. Food Agric. 31, 11581163.

Rachie, K.O., Silvester, P., 1977. Grain Legumes. In: Food crop of the lowland Tropics (Eds.: Leakey, C. L. A., Wiliany, T.B.). Oxford University Press, U.K. pp.41-74.
Thomas, P., Wofford, H.W., 1993. Effect of cadmium and aroclor 1254 on lipid peroxidation glutathione peroxidase activity, and selected antioxidants in Atlantic croaker tissues. Aquatic Toxicol. 27, 159-178.

Tweneboah, C. K., 2000. Modern Agriculture in the Tropics, Food Crops. Co-wood Publishers.

Yamaguchi, M., 1983. World Vegetables. Van Nostrand Reinhold, 115 Fifth Avenue, New York 10003. pp.12-54.

\section{How to cite this article:}

Ukpanukpong, R.U., Bassey, S.O., Ogunbode S. M., Basiru, D. I., Omang, W.A., Eteng, M.U., 2018. Effect of processed Vigna subterranea seed on alkaline phosphatase, conjugated and total bilirubin levels in broiler chickens finishing phase. Int. J. Curr. Res. Biosci. Plant Biol. 5(8), 1-10.

doi: https://doi.org/10.20546/ijcrbp.2018.508.001 